\title{
Splenic Flexure
}

National Cancer Institute

\section{Source}

National Cancer Institute. Splenic Flexure. NCI Thesaurus. Code C12267.

The bend at the junction of the transverse and descending colon. 